\title{
Investigations on Mechanical Properties of Carbon and Glass Fiber Composites with Titanium Oxide and Silicon Dioxide Filler
}

\author{
Saleem Muhammad $^{1 *}$, Yashwanth Tiyyagura ${ }^{1}$, Mallesh Kuruva $^{1}$, Prashanth Kumar Porandla ${ }^{1}$, B.Ch. Nookaraju, Sateesh \\ $\mathrm{N}^{1}, \quad$ Ram Subbaiah ${ }^{1}$ \\ ${ }^{1}$ Department of Mechanical Engineering, Gokaraju Rangaraju Institute of Engineering and Technology, Hyderabad, India
}

\begin{abstract}
The utilization of carbon and glass fiber composites is very extensive in the fields of aviation and automobiles. The strength to weight fraction of these composites is immense. Even though, the modern applications require a lot of improvement in strength. The addition of Nano fillers had brought about significant changes in mechanical properties of the composites. The present work aims at finding out the effects on mechanical properties of composites due to the addition of titanium oxide $10 \%+$ silicon dioxide $10 \%$ hybrid filler. Hand layup process is used for the fabrication of tensile and flexural test specimens which are prepared as per the ASTM standards. The tensile test specimen is D-638 type-iv and the flexural specimen is D-790. Epoxy is used as resin and forms the matrix whereas the carbon and glass fibers act as reinforcement. The comparison is made between the specimens with and without hybrid filler. Two specimens of each type are prepared to have repeatability. The tensile and flexural tests are carried on universal testing machine (UTE-10) and results were obtained. The results showed a significant improvement in tensile and flexural strengths of carbon composites and only flexural strength in glass fibers with hybrid filler.
\end{abstract}

\section{Introduction}

The composite materials are the special kind of materials which are formed by the combination of two or more constituents. The two main constituents of the composite are reinforcement and matrix. The function of former is to bear the load and that of latter is to distribute the load uniformly throughout the whole composite. The reinforcement and matrix in a composite have dissimilar chemical and physical properties. The resulting material formed by the combination of both will have different properties. The constituents within the composite can be distinguished easily as they do not blend with each other. Most of the filler materials which are added to the composites have shown enhancements in the properties of composites. When there is a presence of two or more filler materials or reinforcements within the composites, then those composites are referred to as hybrid composites or composites with hybrid filler. The hybrid composites are a recent advancement in the field of composites which have shown a lot of enhancement in the chemical and physical properties of the composites.

The hybrid composites have become one of the most important engineering materials with an immense range of applications. The properties required by the designer can be tailored by utilizing different matrices and reinforcements. The mechanical properties of the carbon and glass hybrid composites have shown and enhancement as the content of fiber within the matrix material is increased. The addition of small pieces of carbon mat into the composite has enhanced the maximum load, tensile strength and yield strength [1]. The carbon and glass taken in a number of various ratios along with their dispersion states and tensile behaviour of these hybrid composites is studied. As the carbon fiber is dispersed more finely and its content is decreased there is an improvement in the strain at failure point. The behaviour of failure of these hybrid composites is found to be progressive and the material is found to be tougher than the carbon fiber composites [2]. There have been many results which showed that addition of two fibers into the same matrix results in the superior properties. When the fibers of carbon are added to the glass there is an improvement in the flexural strength and vice versa increases the tensile and impact strengths [3].

The carbon fibers are incorporated with graphite Nano particles with increasing weights which acts as the filler material. It is observed that as the weight percentage of graphite filler increases the flexural and tensile properties also increases and the resulting composite is superior mechanical properties when compared with the general carbon fiber [4]. The composite materials are weaker in compression. To improve the compressive properties the epoxy which is matrix material is modified with Nano particles of halloysite, silica and molten rubber. The results obtained have shown significant improvement in the compressive properties of the composite when compared with epoxy matrices [5].

\footnotetext{
* Corresponding author: author@e-mail.org
} 
The glass fiber reinforced epoxy based composite is incorporated with fillers of silicon carbide and graphite. The standards followed are as per the ASTM. The specimens were tested for tensile and flexural strengths. The results obtained from the experimentation concluded that as the loading of fillers increases the strength also increases. As the content of graphite within the composite increases the toughness and flexural strength of the composite also increases [6]. The fiber glass reinforced composite is fabricated with the aid of compression moulding process and silicon dioxide is incorporated as filler. The mechanical behaviour is studied by gradually increasing the filler content. It is found that the increase in filler content improves the hardness, flexural modulus and modulus of elasticity but degrades the elongation and tensile strength of the composite [7].

To reduce the weight of the composite, fly ash is incorporated in the fiber glass reinforced composite with varying content of $2,4,6,8,10$ grams. The results concluded that at 6 grams weight of fly ash the flexural and tensile properties of the fiber glass composites have a greater improvement [8]. A composite consisting of glass fiber, jute fiber, epoxy and aluminium oxide as filler is prepared by varying content of all the constituents each time. The mechanical behaviour of the composite is studied and the results showed that the composites which are filled by $15 \%$ volume of fiber with aluminium oxide have shown a significant improvement in the tensile strength of the composite [9]. The fibers of basalt, glass and carbon when incorporated with various epoxy modifiers like silica, graphite, carbon Nano particles etc, the adhesion properties increases and the load distribution will be uniform [10]. Sateesh, N., Sampath Rao at et conducted to investigate the environmental impacts of fiber composites. The main objective of the work is to investigate the degradation of GFRP composite which is exposed to different environmental conditions and its influence on the tensile strength[11]. Ganesh, R., Subbiah, R at el studied the effect of sintering temperature on physical, mechanical and wear properties of Al 2219 alloy matrix reinforced with $\mathrm{SiC}$ particulates of average particle size $23 \mu \mathrm{m}$ for different weight fractions $10 \%, 15 \%$ and $20 \%$ fabricated by powder metallurgy (PM) method. The influence of sintering temperature on mechanical behavior and dry sliding wear behavior were investigated [12]. Hussaini, S.M., Krishna at el. focused on the development of FLD for austenitic stainless steel (ASS) 316 at $300{ }^{\circ} \mathrm{C}$, which has been experimentally determined to be the most suitable temperature for warm forming of ASS 316 . Experimental FLD has been constructed by performing hemispherical dome punch tests on different width specimens. Theoretical FLDs have been developed using Marciniak-Kuczynski analysis based on Hill's and Barlat's yield criteria and compared with the experimental FLD. Theoretical FLD based on Barlat's yield criterion is found to be in a close agreement with the experimental FLD. These FLDs can be used for designing various warm forming processes on ASS 316[13]. Kotkunde, N., Krishna, G at el has been determined experimentally the FLD for Ti-6Al-4 V alloy at $400{ }^{\circ} \mathrm{C}$ by conducting a hemispherical dome test with specimens of different widths. Additionally, theoretical FLDs have been determined using Marciniak Kuczynski (M-K) model. Various yield criteria namely: Von Mises, Hill 1948, Hill 1993 and Cazacu Barlat in combination with different hardening models viz., Hollomon power law (HPL), Johnson-Cook (JC), modified Johnson-Cook (m-JC), modified Arrhenius (m-Arr.), modified ZerilliArmstrong (m-ZA) have been used in M-K analysis for theoretical FLD prediction. The material properties required for determination of yield criteria and hardening models constants have been calculated using uniaxial tensile tests. The predicted theoretical FLDs results are compared with experimental FLD. It can be observed that influence of yield criterion in $\mathrm{M}-\mathrm{K}$ analysis for theoretical FLD prediction is predominant than the hardening model. Based on the results; it is observed that the theoretical FLD using Cazacu Barlat and Hill 1993 yield criteria with $\mathrm{m}$-Arr. hardening model has a very good agreement with experimental FLD[14]. Hussaini, S.M., Singh, S.K at el. investigated circular blanks are deep drawn at room temperature, $150{ }^{\circ} \mathrm{C}$ and $300{ }^{\circ} \mathrm{C}$ using a 20 ton hydraulic press coupled with a furnace. Finite element simulations are carried out using Dynaform with LS-Dyna solver. Simulations and experimental results show an increase in the limiting drawing ration as the temperature increases and a decrease in the thickness of the drawn cup without any fracture. An artificial neural network model is developed for the prediction of the cup thickness at different locations. Based on the input variables, such as distance from the center of the cup, temperature and LDR, a back propagation neural network model to predict the thickness as output was develop. The comparison between these sets of results indicates the reliability of the predictions. It was found that there is a good agreement between the experimental and predicted values [15].

\section{Experimentation}

\subsection{General Methodology}

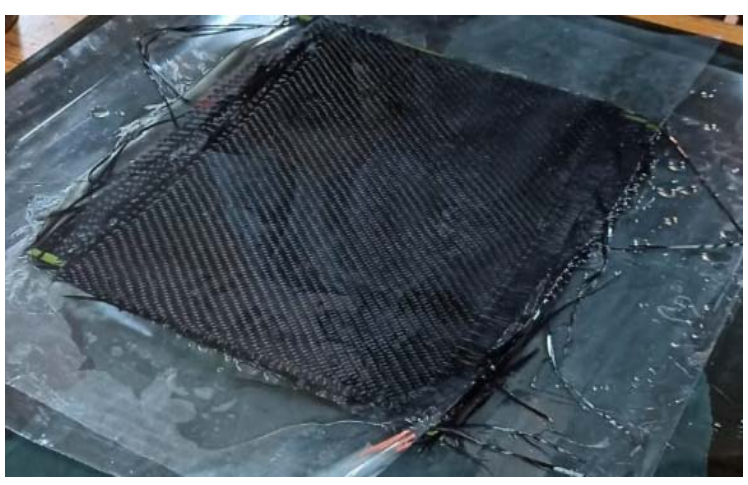

Fig. 1. Hand Layup Process of Carbon Fiber Composite

An investigation has been carried out to study the effect of filler materials (titanium oxide $(10 \%)+$ silicon 
dioxide $(10 \%))$ on the glass and carbon fiber reinforced composites flexural and tensile strengths. The reason aimed at choosing the glass and carbon fiber is due to their extensive use in the field of automobile and construction industries. Epoxy resin has been used for forming the polymer matrix composite with fibers of glass and carbon. The process utilized for fabrication of composites is hand layup process. This process is chosen because of its simplicity and cost effectiveness. Hardener is mixed with the epoxy resin in 1:10 ratio and same amount of accelerator is also added to the resin and the mixture is blended. A base made of glass $0.5 \times 0.5$ square meter is taken and wax is thoroughly applied on it. The epoxy resin is poured on to the mould shape of $300 \times 200$ $\mathrm{mm}$. the fibers are also made into pieces of same dimensions as that of the mould. After pouring the resin it is spread uniformly across the mould with assistance of a paint brush. Then a coating of fiber is placed in the mould and another layer of resin is poured on it. The procedure is repetitive till the anticipated thickness is obtained. Another composite is prepared in the same way as the former; the only change is that while mixing the epoxy with hardener and accelerator the fillers are added in the weight proportion of $10 \%$ of the whole composites. The composites are then cured in the sun for about 5 to 6 hours. Finally, the samples are taken from quadrangular amalgamated composite sheet by using angle grinder and finishing is done by abrasive grinding wheel and filing. The specimen samples are prepared as per the ASTM standards. The specimen measurements used for the tensile test is of D638 type-iv sample. The measurements of flexural test sample are $125 \times 12.7 \times 3.2$ cu.mm. The machine used for carrying out the tests is universal testing machine of model UTE-10. After testing the samples for flexural test and tensile test on the UTM, results are determined. The method of comparisons is laid out between the fibers with and without the fillers and conclusions are made accordingly.

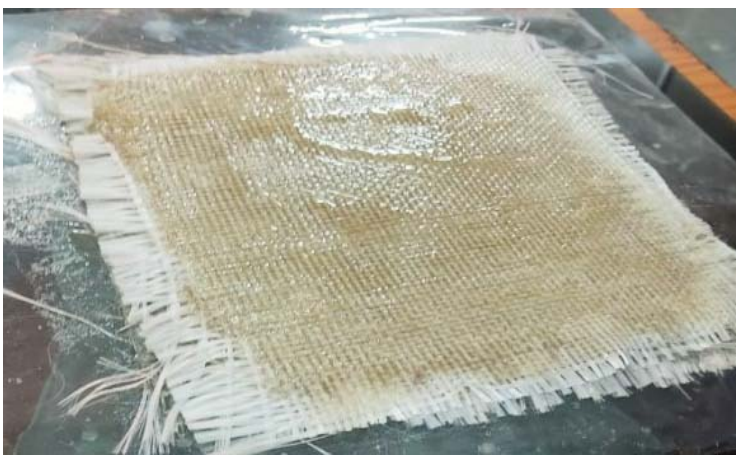

Fig. 2. Hand Layup Process of Glass Fiber Composite

\subsection{Contents by Weight}

The contents of the glass and carbon fiber composites with and without filler by weight are presented below.
Table 1 Contents by Weight without Filler

\begin{tabular}{|c|c|c|c|}
\hline Fiber & $\begin{array}{c}\text { Epoxy } \\
\text { Weight } \\
\text { (Grams) }\end{array}$ & $\begin{array}{c}\text { Fiber } \\
\text { Weight } \\
\text { (Grams) }\end{array}$ & $\begin{array}{c}\text { Total } \\
\text { Weight } \\
\text { (Grams) }\end{array}$ \\
\hline Glass & 260 & 40 & 300 \\
\hline Carbon & 285 & 15 & 300 \\
\hline
\end{tabular}

Table 2 Contents by Weight with Filler

\begin{tabular}{|c|c|c|c|c|}
\hline Fiber & $\begin{array}{c}\text { Epoxy } \\
\text { Weight } \\
\text { (Grams) }\end{array}$ & $\begin{array}{c}\text { Fiber } \\
\text { Weight } \\
\text { (Grams) }\end{array}$ & $\begin{array}{c}\text { Filler } \\
\text { Weight } \\
\text { (Grams) }\end{array}$ & $\begin{array}{c}\text { Total } \\
\text { Weight } \\
\text { (Grams) }\end{array}$ \\
\hline Glass & 200 & 40 & 60 & 300 \\
\hline Carbon & 225 & 15 & 60 & 300 \\
\hline
\end{tabular}

\subsection{Testing of Composites}

The tensile test is carried out in the upper portion of the UTM. To perform a tensile test the specimen of dog bone shape is held between the two jaws. The upper cross head is fixed and the other cross head is movable. As the machine is switched on, the lower jaw begins to move downwards at a uniform arte due to which tensile load is applied on the specimen. The load is applied till the specimen breaks and corresponding readings of the test are recorded in the computer unit.

To perform the flexural test or the compression test on the UTM a special attachment with two supports as shown in the figure is needed. In the flexural test the specimen is in rectangular shape. The specimen is placed in the lower half of the UTM where the upper part is movable and the specimen is placed with a bit of overhang on both the supports which is approximately $10 \%$ of the total length of the specimen. A special attachment is fixed in the movable jaw to apply the load on the specimen. The plunger applies load exactly at the centre till the specimen breaks. The corresponding readings of maximum deformation and the flexural load are noted down from the computer unit. Both the tests are performed at the room temperature. Two specimens of each type are tested for repeatability and average is taken.

\section{Results and Discussions}

The tensile and flexural tests are carried out on universal testing machine of model UTE-10.The specimens are prepared as per the ASTM standards. Carbon and fiber glass specimens are prepared with Nano filler (titanium oxide $(10 \%)+$ silicon dioxide $(10 \%))$ and without filler. Two specimens of each type are prepared and their average reading is taken. The total weight of the carbon and glass fiber composites with and without filler is maintained constant with a uniform thickness of $3 \mathrm{~mm}$. 


\begin{tabular}{|c|c|}
\hline Specimen Type & Flat \\
\hline Specimen Width & $6 \mathrm{~mm}$ \\
\hline Specimen Thickness & $3 \mathrm{~mm}$ \\
\hline Specimen Length & $115 \mathrm{~mm}$ \\
\hline
\end{tabular}

The tensile and flexural test results of the carbon and glass fiber composites with and without filler are presented below. Glass fiber-1, glass fiber-2, carbon fiber-1 and carbon fiber-2 represent the specimens of same kind i.e. either without or with filler which depends on the table they are presented in. The ultimate load is averaged for two specimens and divided by the original cross section area of the tensile specimens to get the ultimate tensile strength of the composite and to obtain the flexural strength of the composite the formula GFL $k$ 2bd' is used. Where ' $\mathrm{P}$ ' is load, 'L'is length of the specimen, ' $b$ ' is breadth and ' $\mathrm{d}$ 'is depth of thickness of the specimen which is $3 \mathrm{~mm}$.

Table 4 Tensile Test Results of Glass fibres without Filler

\begin{tabular}{|c|c|c|c|}
\hline & $\begin{array}{c}\text { Glass } \\
\text { Fibre-1 }\end{array}$ & $\begin{array}{c}\text { Glass } \\
\text { Fibre-2 }\end{array}$ & Average \\
\hline $\begin{array}{c}\text { Ultimate } \\
\text { Load }\end{array}$ & $3.095 \mathrm{kN}$ & $3.495 \mathrm{kN}$ & $3.295 \mathrm{kN}$ \\
\hline $\begin{array}{c}\text { Ultimate } \\
\text { Tensile } \\
\text { Strength }\end{array}$ & $171.95 \mathrm{MPa}$ & $194.17 \mathrm{MPa}$ & $183.06 \mathrm{MPa}$ \\
\hline
\end{tabular}

Table 5 Tensile Test Results of Glass fibres with Filler

\begin{tabular}{|c|c|c|c|}
\hline & $\begin{array}{c}\text { Glass } \\
\text { Fibre-1 }\end{array}$ & $\begin{array}{c}\text { Glass } \\
\text { Fibre-2 }\end{array}$ & Average \\
\hline $\begin{array}{c}\text { Ultimate } \\
\text { Load }\end{array}$ & $2.945 \mathrm{kN}$ & $2.770 \mathrm{kN}$ & $2.8575 \mathrm{kN}$ \\
\hline $\begin{array}{c}\text { Ultimate } \\
\text { Tensile } \\
\text { Strength }\end{array}$ & $163.61 \mathrm{MPa}$ & $153.89 \mathrm{MPa}$ & $158.75 \mathrm{MPa}$ \\
\hline
\end{tabular}

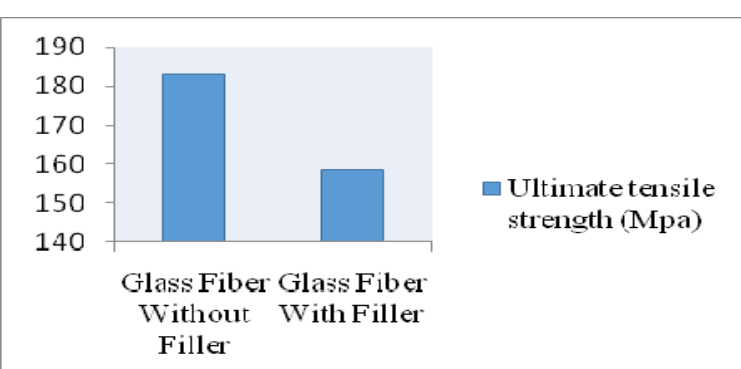

Fig. 3. Average Ultimate Tensile Strength of Glass Fiber

Table 6 Tensile Test Results of Carbon fibres without Filler

\begin{tabular}{|c|c|c|c|}
\hline & $\begin{array}{c}\text { Carbon } \\
\text { Fibre-1 }\end{array}$ & $\begin{array}{c}\text { Carbon } \\
\text { Fibre-2 }\end{array}$ & Average \\
\hline $\begin{array}{c}\text { Ultimate } \\
\text { Load }\end{array}$ & $2.995 \mathrm{kN}$ & $3.228 \mathrm{kN}$ & $3.1115 \mathrm{kN}$ \\
\hline $\begin{array}{c}\text { Ultimate } \\
\text { Tensile } \\
\text { Strength }\end{array}$ & $166.389 \mathrm{MPa}$ & $\begin{array}{c}179.33 \\
\mathrm{MPa}\end{array}$ & $\begin{array}{c}172.8595 \\
\mathrm{MPa}\end{array}$ \\
\hline
\end{tabular}

Table 7 Tensile Test Results of Carbon fibres with Filler

\begin{tabular}{|c|c|c|c|}
\hline & $\begin{array}{c}\text { Carbon } \\
\text { Fibre-1 }\end{array}$ & $\begin{array}{c}\text { Carbon } \\
\text { Fibre-2 }\end{array}$ & Average \\
\hline $\begin{array}{c}\text { Ultimate } \\
\text { Load }\end{array}$ & $3.725 \mathrm{kN}$ & $3.285 \mathrm{kN}$ & $3.505 \mathrm{kN}$ \\
\hline $\begin{array}{c}\text { Ultimate } \\
\text { Tensile } \\
\text { Strength }\end{array}$ & $206.95 \mathrm{MPa}$ & $182.5 \mathrm{MPa}$ & $194.72 \mathrm{MPa}$ \\
\hline
\end{tabular}

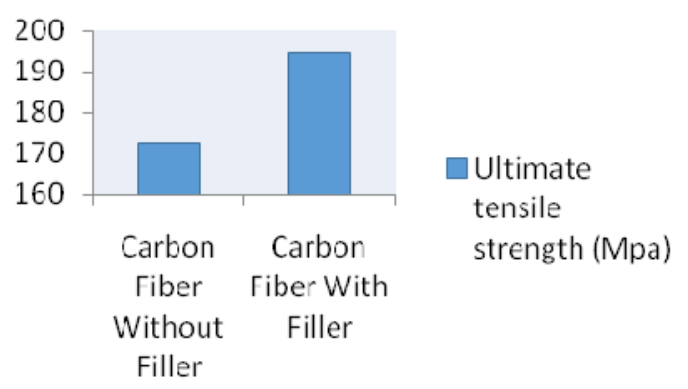

Fig. 4. Average Ultimate Tensile Strength of carbon Fiber

Table 8 Flexural Test Results of Glass Fibre without Filler

\begin{tabular}{|c|c|c|c|}
\hline & $\begin{array}{c}\text { Glass } \\
\text { Fibre-1 }\end{array}$ & $\begin{array}{c}\text { Glass } \\
\text { Fibre-2 }\end{array}$ & Average \\
\hline $\begin{array}{c}\text { Flexural } \\
\text { Load }\end{array}$ & $0.475 \mathrm{kN}$ & $0.455 \mathrm{kN}$ & $0.465 \mathrm{kN}$ \\
\hline $\begin{array}{c}\text { Flexural } \\
\text { Strength }\end{array}$ & $547.87 \mathrm{MPa}$ & $524.81 \mathrm{MPa}$ & $\begin{array}{c}536.34 \\
\mathrm{MPa}\end{array}$ \\
\hline
\end{tabular}

Table 9 Flexural Test Results of Glass Fibre with Filler

\begin{tabular}{|c|c|c|c|}
\hline & $\begin{array}{c}\text { Glass } \\
\text { Fibre-1 }\end{array}$ & $\begin{array}{c}\text { Glass } \\
\text { Fibre-2 }\end{array}$ & Average \\
\hline $\begin{array}{c}\text { Flexural } \\
\text { Load }\end{array}$ & $0.540 \mathrm{kN}$ & $0.508 \mathrm{kN}$ & $0.524 \mathrm{kN}$ \\
\hline $\begin{array}{c}\text { Flexural } \\
\text { Strength }\end{array}$ & $622.85 \mathrm{MPa}$ & $585.94 \mathrm{MPa}$ & $\begin{array}{c}604.40 \\
\mathrm{MPa}\end{array}$ \\
\hline
\end{tabular}

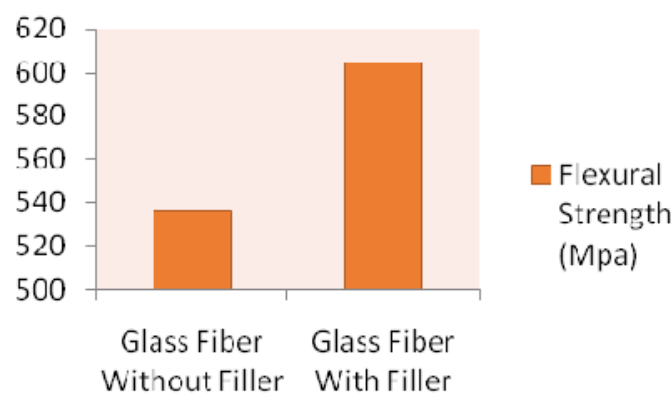

Fig. 5. Average Flexural Strength of Glass Fiber

Table 10 Flexural Test Results of Carbon Fibre without Filler

\begin{tabular}{|c|c|c|c|}
\hline & $\begin{array}{c}\text { Carbon } \\
\text { Fibre-1 }\end{array}$ & $\begin{array}{c}\text { Carbon } \\
\text { Fibre-2 }\end{array}$ & Average \\
\hline $\begin{array}{c}\text { Flexural } \\
\text { Load }\end{array}$ & $0.525 \mathrm{kN}$ & $0.505 \mathrm{kN}$ & $0.515 \mathrm{kN}$ \\
\hline $\begin{array}{c}\text { Flexural } \\
\text { Strength }\end{array}$ & $605.54 \mathrm{MPa}$ & $582.48 \mathrm{MPa}$ & $\begin{array}{c}594.01 \\
\mathrm{MPa}\end{array}$ \\
\hline
\end{tabular}


Table 11 Flexural Test Results of Carbon Fibre with Filler

\begin{tabular}{|c|c|c|c|}
\hline & $\begin{array}{c}\text { Carbon } \\
\text { Fibre-1 }\end{array}$ & $\begin{array}{c}\text { Carbon } \\
\text { Fibre-2 }\end{array}$ & Average \\
\hline $\begin{array}{c}\text { Flexural } \\
\text { Load }\end{array}$ & $0.540 \mathrm{kN}$ & $0.548 \mathrm{kN}$ & $0.544 \mathrm{kN}$ \\
\hline $\begin{array}{c}\text { Flexural } \\
\text { Strength }\end{array}$ & $622.85 \mathrm{MPa}$ & $632.08 \mathrm{MPa}$ & $\begin{array}{c}627.475 \\
\mathrm{MPa}\end{array}$ \\
\hline
\end{tabular}

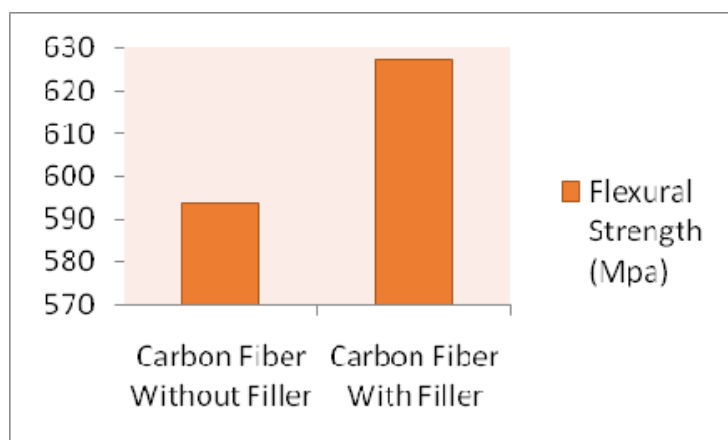

Fig. 6. Average Flexural Strength of Carbon Fiber

The percentage change in the tensile and flexural strength are determined below to study the effect of (titanium oxide $(10 \%)+$ silicon dioxide $(10 \%))$ Nano filler on the carbon and fiber glass composites.

Table 12 Percentage change in tensile strength of glass and carbon fiber

\begin{tabular}{|c|c|c|c|c|}
\hline $\begin{array}{l}\text { Ultimate } \\
\text { Tensile } \\
\text { Strength } \\
\text { (MPa) }\end{array}$ & $\begin{array}{l}\text { With } \\
\text { Filler } \\
\text { (A) }\end{array}$ & $\begin{array}{c}\text { Without } \\
\text { Filler (B) }\end{array}$ & $\begin{array}{c}\text { Increase } \\
\text { Or } \\
\text { Decrease } \\
\text { (A-B) }\end{array}$ & $\begin{array}{c}\text { \%Change } \\
\left(\frac{A=-H}{d} X 100\right)\end{array}$ \\
\hline $\begin{array}{l}\text { Glass } \\
\text { fiber }\end{array}$ & 158.75 & 183.06 & -24.31 & $-13.28(\downarrow)$ \\
\hline $\begin{array}{c}\text { Carbon } \\
\text { fiber }\end{array}$ & 194.72 & 172.86 & 21.86 & $12.65(\uparrow)$ \\
\hline
\end{tabular}

Table 12 Percentage change in flexural strength of glass and carbon fiber

\begin{tabular}{|c|c|c|c|c|}
\hline $\begin{array}{c}\text { Flexural } \\
\text { Strength } \\
\text { (MPa) }\end{array}$ & $\begin{array}{l}\text { With } \\
\text { Filler } \\
\text { (A) }\end{array}$ & $\begin{array}{c}\text { Without } \\
\text { Filler } \\
\text { (B) }\end{array}$ & $\begin{array}{c}\text { Increase } \\
\text { Or } \\
\text { Decrease } \\
\text { (A-B) }\end{array}$ & $\begin{array}{l}\text { \% Change } \\
\left(\frac{i=4}{6} \times 100\right)\end{array}$ \\
\hline $\begin{array}{l}\text { Glass } \\
\text { fiber }\end{array}$ & 604.40 & 536.34 & 68.06 & 12.69 fin \\
\hline $\begin{array}{c}\text { Carbon } \\
\text { fiber }\end{array}$ & 627.475 & 594.01 & 33.465 & $5.63 \mathrm{st}$ \\
\hline
\end{tabular}

\section{CONCLUSIONS}

A comparison is made between the specimens of glass and carbon fiber with and without the filler material for the tensile and flexural strengths. The results obtained with the addition of filler material (titanium oxide $10 \%+$ silicon dioxide 10\%) have shown significant improvements in the carbon fiber reinforced composite's tensile strength and in flexural strength of both fiber glass and carbon reinforced composites. The Ultimate Tensile strength of the fiber glass reinforced composite has shown a declination.
From the results obtained for with and without filler material composites of the fiber glass and carbon reinforced plastics for the tensile and flexural tests following can be concluded.

- Filler materials add-on has shown declination in the ultimate tensile strength of fiber glass reinforced composites by $13.28 \%$.

- Filler materials add-on has enhanced the ultimate tensile strength of the carbon fiber reinforced composites by $12.65 \%$.

- Filler materials add-on has enhanced the flexural strength of the fiber glass reinforced composites by $12.69 \%$.

- Filler materials add-on has enhanced the flexural strength of the carbon fiber reinforced composites by $5.63 \%$.

The overall above results conclude that the addition of filler materials of titanium oxide and silicon dioxide $10 \%$ each by weight will have a positive impact over the tensile and flexural strengths of the carbon fiber reinforced composites and flexural strength of the glass fiber reinforced composites.

\section{REFERENCES}

1. T D Jagannatha, G Harish. International Journal of Mechanical Engineering and Robotics Research 4, 131 (2015).

2. P.W.Manders, M.G.Bader, Journal of Material Science 16, 2233 (1981).

3. J.Summerscales, D.Short, , Science Direct 9, 157 (1978).

4. Ricardo Baptista, Ana Mendão, Mafalda Guedes, Rosa Marat-Mendes, Procedia Structural Integrity 1, 74 (2016).

5. Fang Liu, Shiqiang Deng, Jianing Zhang, Journal of Nanomaterials 2017, 1 (2017).

6. Basappa Hulugappa, Mysuru V. Achutha, Bheemappa Suresha, Journal of Minerals and Materials Characterization and Engineering 4, 1 (2016).

7. B Shivamurthy, Siddaramaiah, M.S. Prabhuswamy, Journal of Minerals and Materials Characterization and Engineering 8, 513 (2009).

8. S.Pichi Reddy, P.V. Chandra Sekhar Rao, A.Chennakesava Reddy, "International Conference on Advanced Materials and Manufacturing Technologies", 1, 1 (2014).

9. Aslamjaved I K, Basappa N K, International Journal of Engineering Research \& Technology 10, 177 (2021).

10. Matykiewicz D, A Review of Mechanical and Thermomechanical Prioperties", Materials (Basel) 13, 1 (2020).

11. Sateesh, N., Sampath Rao, P., Ravishanker, D.V., Satyanarayana, K, Materials Today: Proceedings, 2, 2902 (2015). 
12. Ganesh, R., Subbiah, R., Chandrasekaran, K. Materials Today: Proceedings, 2, 1441 (2015).

13. Hussaini, S.M., Krishna, G., Gupta, A.K., Singh, S.K., Journal of Manufacturing Processes, 18, 151 (2015).

14. Kotkunde, N., Krishna, G., Shenoy, S.K., Gupta, A.K., Singh, S.K. International Journal of Material Forming, 10, 255 (2017).

15. Hussaini, S.M., Singh, S.K., Gupta, A.K, Journal of Materials Research and Technology, 3, 17 (2014). 